\title{
EFL STUDENTS' EXPERIENCES IN LEARNING CALL THROUGH PROJECT BASED INSTRUCTIONS
}

\author{
Yustinus Calvin Gai Mali \\ (yustinus.calvin@staff.uksw.edu) \\ Universitas Kristen Satya Wacana, Salatiga, Indonesia \\ Jl. Diponegoro 52 - 60, Salatiga 50711, Indonesia
}

\begin{abstract}
Various initiatives led by Ministries of Education and related entities in many countries around the world have encouraged teachers not only to integrate technology in their teaching practices but also to employ various sound teaching methods that allow learners to be actively involved in the teaching and learning process. As a response to these issues, this qualitative study delves closely into students' perspectives on the implementation of Project Based Learning (PBL) activities in an Introduction to Computer Assisted Language Learning (ICALL) course. Thirty students participated in the study by submitting reflective notes that answer four questions concerning the implementation of PBL in the course. Approached through the lens of content analysis paradigms, the data analysis results showed the students' positive responses to the employment of PBL in exploring potential technology for language teaching and learning purposes. Implications for ICALL course designs particularly in English as a Foreign Language (EFL) higher education context and directions for further research were also discussed.
\end{abstract}

Keywords: CALL, PBL, project-based learning, projects, collaboration, EFL

DOI: http://dx.doi.org/10.15639/teflinjournal.v28i2/170-192

In the early year of 2016, I had the opportunity to teach the Introduction to Computer Assisted Language Learning (ICALL) course at the English Language Education Study Program, Kebahagiaan University Indonesia (ED-KU) (anonymous). The course is offered as an elective subject to upper-semester students in the study program. By the end of the course, the students are ex- 
pected to [1] be familiar with and be able to utilize some forms of technology for language teaching and learning, and [2] be able to create a lesson plan that incorporates the use of technology in the process of language teaching and learning.

At the end of the course, I felt the necessity to reflect on the learning activities the students did in the classroom, specifically on the two main projects designed using Project Based Learning (PBL) framework, so that I can obtain valuable insights for the improvement of the teaching and learning activities in the following semesters. The reflection explored my students' perspectives of the PBL practices in their course and was particularly guided by four main research questions that helped to look at what the students did in their classroom, why they did it and whether they thought it worked or not. The four questions were:

1. What are the advantages of the PBL activities done in the ICALL classroom?

2. What are the challenges of the PBL activities done in the ICALL classroom?

3. What parts of the course do the students like most?

4. What parts of the course do the students find challenging?

The research will be of interest to those implementing and researching PBL in higher education courses. It will also benefit those teaching ComputerAssisted Language Learning (CALL) courses in EFL contexts, particularly in the context of higher education in Indonesia. Furthermore, the paper will be fruitful for those interested in integrating PBL and CALL into their classroom practices and who wish to explore more ideas of how students may benefit from PBL and the integration of technology in higher education teaching and learning context. The research will also help to broaden EFL teachers' horizons especially in relation to how PBL is implemented and how CALL is taught and learned in an Indonesian EFL setting. In the following, relevant literature regarding PBL and CALL will be reviewed.

PBL covers multi-faceted learning concepts of active learning, collaborative learning, problem-based learning, and learning autonomy. It is a social practice into which learners are socializing through a series of group activities involving simultaneous learning of language, content, and skills (Slater, Beckett, \& Aufderhaar, 2006). It is also a collaborative learning that provides learners with opportunities to "[...] work together to solve a problem and learn from each other as they co-construct knowledge" (Whatley, 2012, p. 77). Furthermore, PBL is a self-directed form of learning in which students work actively 
and collaboratively in small groups to seek answers to their questions and to conduct a comprehensive investigation into a problem (Lam, Cheng, \& Ma, 2009). It does therefore espouse principles of learner-centered teaching, learning autonomy, and learning through tasks (Hedge, 2000). As a form of learnercentered teaching, PBL allows students to be involved in an active learning experience for the purpose of solving problems in groups (Brown, 2007; Felder, 2015), and at the same time encourages them to be autonomous learners who are able to take responsibility for their own learning (Richards, 2015).

The literature has extensively discussed the advantages of PBL in language teaching and learning. For instance, PBL has the capacity in teaching $21^{\text {st }}$-century skills, such as collaboration and problem solving (Mosier, Bradley-Levine, \& Perkins, 2016). It enables active beyond-classroom exploration to a particular subject (Lattimer \& Riordan, 2011) and helps students to achieve greater understanding of a topic and increases their learning motivation (Bell, 2010). Moreover, teamwork project, the core of PBL, can help learners to be actively engaged in a learning process (Neal, Ho, Weihs, Hussain, \& Cinar, 2011). Besides, PBL provides opportunities for them to work cooperatively in small groups in which they can share resources and ideas in completing a particular project (Stoller, 2002). Performing a group work promotes responsibility to progress upon each member of the group (Brown, 2001), encourages broader skills of cooperation and negotiation, and enables various contributions from group members (Harmer, 2007). Neal et al. (2011) suggests that “[...] when students work together in a group to solve an authentic problem, it can assist them in developing content knowledge and such skills as problemsolving, reasoning, and communication" (p.102). Doing a group work also "[...] improves motivation and contributes to a feeling of cooperation and warmth in the classroom" (Ur, 1996, p. 232). PBL has thus been "[...] advocated as an effective means of promoting language and content learning in EFL classrooms" (Guo, 2006, p. 147).

The implementation of PBL has not been without some challenges. From the learners' point of view, working in groups can cause interpersonal conflicts and unequal distributions of workload among the group members (Walker, 2001). From the instructors' point of view, it is not possible to assess the quality of the final products of PBL objectively without being well informed of the working process of the group (Lee \& Lim, 2012). Another challenge for those implementing PBL deals with promoting "a balance between an excessive teacher control versus an absence of teacher feedback and guidance during the 
process" (Dooly \& Masats, 2008, p. 32). Moreover, the implementation of PBL is generally time-consuming (Baysura, Altun, \& Yucel-Toy, 2015). In implementing PBL, therefore, there are a number of aspects that need to be considered to capitalize on the strengths and reduce the weaknesses of this particular approach.

PBL in this study is used as a method to learn about CALL. In brief, CALL deals with the use of computers, software, and online learning materials for teaching and learning a second language (Chapelle \& Jamieson, 2008). It is about the use of computers in the learning and teaching of foreign languages maximizing the use of word-processors (Davies \& Riley, 2012) and Internet applications, such as e-mail, chat, and the World Wide Web (WWW) for language learning purposes (Torat, 2000). According to Li and Hart (2002), WWW is "a system for accessing and viewing information on the Internet" (p.374). CALL can also be seen as an approach to language teaching and learning in which teachers use the computer as an aid to present, reinforce, and assess materials that the students learn (Davies, 2016). Thus, CALL can facilitate language use, promote language learning, and help students to complete language-learning tasks and achieve their classroom learning objectives.

Literature has reported trends of CALL, particularly in higher education settings. Johnson and Brine (1999) implemented projects of e-mail for communicative exchanges, in which students were paired with native speakers in other countries, to learn EFL in a university in central Japan. Before running the projects, the students were introduced to the basic knowledge of software and computer devices. Afterwards, the students took a variety of paper-based drills and quizzes to get familiar with basic computer and software terminology. Foss, Carney, McDonald, and Rooks (2007) researched the effectiveness of project-based teaching approach implemented in a short-term intensive English program for Japanese university EFL students. The theme of the program covered the relationship between science and ethics. The program implemented four different projects, namely the Wikipedia project, the newspaper project, the small-group video project, the whole-group video project. The results of the study suggest that project-based instruction becomes a viable alternative to traditional intensive English coursework. More recently, Yildiz-Genc (2011) informed that technology integration is one of the general principles of the new content-based EFL curriculum at a Turkish university. Yildiz-Genz documented a plan to increase the number and use of computer labs to promote CALL and to expose students to authentic materials through the Internet. In addition, 
teachers are asked to conduct research on CALL related topics and share the results with their colleagues during a workshop. It is believed that CALL is crucial for students to be autonomous in learning a second language. Alresheed, Leask, \& Raiker (2015) reported that the government of Saudi Arabia aims to "[...] provide most educational institutions with computers and networking for integrating CALL into classrooms" (2015, p.69).

As a positive response to the educational policy in Indonesia and the need of technology integration, ED-KU possesses an explicit mission statement that encourages teachers and students to integrate technology and maximize its potentials in their teaching and learning practices. As a real actualization of the mission statement, ED-KU offers the ICALL course to introduce potentials of technology for the students who are prepared to be English language teachers in the future.

\section{METHOD}

The present qualitative study delved closely into students' perspectives on the advantages and challenges of the implementation of PBL activities in the ICALL course as well as on the preferable and challenging parts of the course. As an attempt to capture a particular experience that will lead to a richer description and a deeper understanding of the experience of my students, I approached the study using content analysis that deals with "[...] the process of summarizing and reporting written data" (Cohen, Manion, \& Morrison, 2007, p. 475).

The site of the study was in a face-to-face two-credit-hour ICALL course at ED-KU from January to April 2016. It involved thirty students aged twenty to twenty-two years old. To retain the confidentiality of the participants, I recorded their names in initials. The teaching and learning process of the course was done in the computer laboratory, in which every student had access to a computer connected to the Internet.

In the ICALL course, I limited the number of students who worked in a group to three in order to minimize unequal distributions of their workload. After the class ended, I usually stayed around for another fifteen minutes in the classroom to give the students opportunities to discuss their projects. In addition to the in-class consultation, they were welcome to see me during my office hour to report progress of their projects. These face-to-face consultations 
helped me to ensure that the students obtained sufficient guidance in completing their projects.

This section provides some details about the two main projects and learning activities of the projects in the course, which henceforth I call as the PBL activities. The two projects were adapted from a classroom syllabus developed by Isharyanti (2015). Both projects were done in groups of three students. The first project was a technology workshop project. In this project, the students had to prepare PowerPoint slides to be presented to their classmates. The topic of the presentation was based on the course syllabus that provides the students with some topics, such as a blog, social networking sites, and Google facilities. In the first meeting of the course, the students were asked to choose their group members and work in groups. Then, I randomly chose the topic in the syllabus to be presented every week by each group. The presentation had to be supported by, at least, three supporting references that the students can access from any reliable sources on the Internet or relevant books available in the campus library.

During the presentation, each group had to evaluate one particular technology. The evaluation was based on the principles of CALL evaluation by Chapelle (2001). The principles require the students to explain (1) the purposes of the tasks they create from the chosen technology, (2) how the task fits learners in a particular setting, and whether (3) the technology is interactive and (4) can be used to provide feedback for students. Further, the students have to explain how the technology (5) provides learners with language learning activities, (6) is appropriate to learners of a particular age, (7) enables them to use the target language to complete a specific task, and (8) provides them with the opportunities to perform authentic tasks or those they encounter outside the classroom. Lastly, the groups had to explain (9) some potentials of the technology for language learning. Table 1 lists some of the technology the groups presented in the classroom.

Table 1. Educational Technology Presented by the Groups

\begin{tabular}{lllc}
\hline \multicolumn{1}{c}{$\begin{array}{c}\text { Online } \\
\text { Technology }\end{array}$} & \multicolumn{1}{c}{ Website } & \multicolumn{1}{c}{ Potentials } & Group \\
\hline google + & https://plus.google.com/ & $\begin{array}{l}\text { Share learning mate- } \\
\text { rials }\end{array}$ & 1 \\
\hline abcya & http://abcya.com/ & $\begin{array}{l}\text { Access online vocab- } \\
\text { ulary games }\end{array}$ & 2 \\
\hline
\end{tabular}


176 TEFLIN Journal, Volume 28, Number 2, July 2017

\begin{tabular}{|c|c|c|c|}
\hline $\begin{array}{c}\text { Online } \\
\text { Technology }\end{array}$ & Website & Potentials & Group \\
\hline titanpad & https://titanpad.com/ & $\begin{array}{l}\text { Utilize an online col- } \\
\text { laborative writing } \\
\text { platform }\end{array}$ & 3 \\
\hline coggle.it & https://coggle.it/ & $\begin{array}{l}\text { Utilize an online } \\
\text { mind-mapping }\end{array}$ & 4 \\
\hline ed.ted & http://ed.ted.com/ & Download video files & \\
\hline $\begin{array}{l}\text { famous people } \\
\text { lessons }\end{array}$ & $\begin{array}{l}\text { http://www.famouspeopleless } \\
\text { ons.com/ }\end{array}$ & \multirow[t]{2}{*}{$\begin{array}{l}\text { Download listening } \\
\text { audio files }\end{array}$} & \multirow[t]{2}{*}{5} \\
\hline $\begin{array}{l}\text { breaking news } \\
\text { English }\end{array}$ & $\begin{array}{l}\text { http://www.breakingnewsengli } \\
\text { sh.com/ }\end{array}$ & & \\
\hline guess the words & $\begin{array}{l}\text { https://www.facebook.com/Gu } \\
\text { essTheWord/ }\end{array}$ & \multirow{3}{*}{$\begin{array}{l}\text { Access online vocab- } \\
\text { ulary } \\
\text { Games }\end{array}$} & \multirow[t]{3}{*}{6} \\
\hline guess the idiom & $\begin{array}{l}\text { https://www.facebook.com/gu } \\
\text { esstheidiom }\end{array}$ & & \\
\hline wordox & $\begin{array}{l}\text { https://www.facebook.com/W } \\
\text { ordox/ }\end{array}$ & & \\
\hline duolingo & $\begin{array}{l}\text { https://www.duolingo.com/co } \\
\text { urse/en/ar/Learn-English- } \\
\text { Online }\end{array}$ & \multirow{2}{*}{$\begin{array}{l}\text { Access various } \\
\text { online educational } \\
\text { materials } \\
\text { to learn English }\end{array}$} & \multirow[t]{2}{*}{7} \\
\hline memrise & $\begin{array}{l}\text { http://www.memrise.com/cour } \\
\text { ses/english/english/ }\end{array}$ & & \\
\hline
\end{tabular}

After their presentation, the groups conducted a mini workshop on the activities discussed in the presentation. The workshops were conducted so that students in the other groups could experience the implementation of the evaluated technology in language learning contexts. Each group was given ninety minutes to run their workshop in which every group member had to present and be involved. For instance, group 1 showed the potentials of Google + in teaching and learning descriptive writing, while groups 2 and 4 discussed the use of educational websites, abcya.com and ed.ted.com, in learning listening, grammar, and vocabulary. During the workshop, the other students in the classroom were allowed to ask for clarification and ask for assistance during their practice in utilizing the technology from the members of the group who were presenting. After the group presentation, the other students were asked to post their constructive feedback to the tutor blog, the one I utilized to facilitate the learning in the class, concerning the students' performance during their presentation (see Figure 1). 
thank you Bram's group for sharing with us about the use of facebook for learning process. I like the game sites which encourage the students to arrange the alphabet. however, in my opinion, facebook is not really effective since we cannot control all our students stay on our page.Anyway, that is interesting.

\section{Reply Delete}

DI I think Google+ can be used for academic purposes like the one we practiced in class today. But I think it will work most effectively if used in real time so the teacher can give the feedback to the students right away. If it's used to submit a homework or assignment that the teacher wouldn't be able to assess right away, it would be less effective, because there's the edit feature in each post, so the students will be able to edit their submission before the teacher can check it. But overall it was quite an interesting experience.

Reply Delete

Figure 1: The Comments Posted in the Blog

The second project was the lesson plan project. In this project, the students had to work in the same group to create three lesson plans based on the topics provided in the course syllabus. My basic assumption was that the students understood a standard lesson plan format as they had completed their teaching practicum program that required them to create lesson plans. Therefore, during the course, I did not re-explain the concepts and formats of lesson plan and the procedures of development.

In the three lesson plans, the groups had to include five essential components: (1) course information, (2) technology requirements, (3) activities design, (4) students assessment, and (5) caveats. In the course information part, the students provided some details about the learning objectives, skills to learn (e.g., speaking, listening, writing, or reading), and the level of their target learners. In the technology requirement part, the students listed the hardware, software, and supporting facilities needed to run the activities they have created. In the activities design part, the students described at least three learning activities. Then, they explicated the names and duration for each activity. Following the explication, they detailed the references, websites, or software they used to support the activities. In the students' assessment part, a criterion of how learners are going to be assessed had to be explained clearly. If the students adopted evaluation forms from the Internet or other sources, they had to 
acknowledge the sources accordingly in the references. In the caveats part, the students stated possible considerations for teachers who wish to apply the lesson plan, including requirements, problems, and other important details.

Data on the students' perspectives on the issues of the implementation of PBL in ICALL course were collected using reflective notes. The notes were completed over a month period (February 2016). I explained the questions to be answered in the reflective notes in a classroom meeting held in the first week of February. I told the students that the questions were written in English and they were required to answer the questions using the same language. Then, they were supposed to write their answers on pieces of paper and completed this activity outside the classroom. The notes were submitted in the classroom meeting on the fourth week of February 2016. To explore the issues raised by the students, I read their responses and circled some ideas that they needed to clarify further. On the first week of March, I returned the notes to the students and asked them to elaborate the circled responses in the classroom meeting. The students provided further written elaborations on the same paper fifteen minutes before the class ended.

To analyze the students' written responses, I adapted the content analysis guidelines that define a process of summarizing, reporting written data, and examining emergent nature of themes from the data by Cohen et al. (2007). Initially, I read all the written data. Then, I defined the units of analysis by underlining sentences that indicated advantages and challenges of PBL in learning CALL, parts of the course that the students like and find challenging. That step was followed by deciding the codes to be used in the analysis. Later, I wrote some words to label the underlined sentences indicating the issues. After I had written the codes, I started to develop them into themes in relation to the four research questions of the study. Some excerpts of the students' reflective notes were recorded to support the discussions of every theme.

\section{FINDINGS AND DISCUSSION}

\section{Findings}

This section is divided into four main sub-sections based on the research questions, namely the advantages of the PBL activities in learning CALL, the 
challenges of the PBL activities in learning CALL, the preferable parts of the course, and the challenging parts of the course.

\section{Advantages of the PBL Activities in Learning CALL}

The data analysis results reveal some primary advantages of the implementation of PBL activities in the ICALL course: learning from each other, promoting learning autonomy, and practicing cooperation skills. Table 2 summarizes the students' responses regarding the advantages of the PBL activities in learning CALL. It is shown in Table 2 that more than half of the students were of the opinion that learning from each other was the main advantage of the PBL activities. They mentioned that the PBL activities enabled them to learn a particular technology from their group mates as well as from other students in the other groups. Two students shared their perspectives:

"I learn something that I do not know before from friends in my group. We can share our knowledge about particular technology, explore some applications, and discuss things related to educational technologies" (student8/LEO).

"From the first group presentation, we learn Google + . Though we could not explore all the facilities on Google +, it gave us ideas if we someday have to teach using a computer in our classroom" (student10/LEO).

Another well-noted advantage was promoting learning autonomy to the students. Some students clarified their perspectives:

"In class, students often get the lesson directly from the teacher, but through project given to them; they are pushed to dig more what they are learning in the class" (student13/PLA).

"We do not need the teacher to explain all the time, but we can share each other's knowledge" (student14/PLA).

Some students also wrote that the PBL activities provided them with the opportunities to practice their cooperation skills.

"Completing the project taught me a lesson. It is not easy to work with other people because we have different ideas and a mindset. I learn to face the differences and combine them to become one solid project" (student5/PCS). 
Another student expressed her similar thought:

"In finishing the lesson plan, every person has different perspectives in seeing and solving problems. From this case, we learn to appreciate friends' work and unite the differences without hurting anyone" (student13/PCS).

Other advantages that the students considered important were sharing responsibilities in completing a project, practicing to be an open-minded person, and promoting a relaxed atmosphere in the group. Interestingly, it was mentioned that the PBL activities enable the teacher to learn new technology from his students, as what one student wrote in her notes:

"In the class, I did not see the teacher dominate the class like the conventional practices where the teacher is the center of the learning. Moreover, the teacher can learn something new from the projects delivered by the students" (student16/LFS).

Table 2. Advantages of the PBL Activities in Learning CALL $(n=34)$

\begin{tabular}{lcc}
\hline Student Responses & $\boldsymbol{f}$ & $\%$ \\
\hline Learn from each other & 21 & 61 \\
\hline Promote learning autonomy & 5 & 14 \\
\hline Practice a cooperation skill & 3 & 9 \\
\hline Share a responsibility to complete a project & 2 & 6 \\
\hline Enable the teacher to learn technology from his students & 2 & 6 \\
\hline Practice to be an open-minded person & 1 & 2 \\
\hline Promote a relaxed atmosphere in the group & 1 & 2 \\
\hline
\end{tabular}

\section{Challenges of the PBL Activities in Learning CALL}

The students found poor Internet connection, time arrangement, and negative attitudes to be three of the most challenging factors of the implementation of PBL activities in the ICALL course. Table 3 summarizes what the students thought to be the challenges of the PBL activities done in the classroom. Poor Internet connection in the campus area was perceived to be the main challenge. Some students wrote the issue on their notes:

"I cannot follow the instruction of my friend because the Internet connection is too slow. This is very frustrating. While I am still waiting for the website, other friends have already moved one step forward" (student6/PIC). 
Some students felt that they found it difficult to arrange time to discuss with their group members:

"We could hardly find a time to meet and do the task together. If ones could make it, then the other one could not. That was why we sometimes decided to do the job individually after all" (student7/ATD).

Table 3. Challenges of the PBL Activities in Learning CALL ( $n=28)$

\begin{tabular}{lcc}
\hline \multicolumn{1}{c}{ Students Responses } & $\boldsymbol{f}$ & $\mathbf{\%}$ \\
\hline Experience poor Internet connection in the campus area & 8 & 28 \\
\hline Arrange a time to discuss with group members & 5 & 17 \\
\hline Students' negative attitudes & 4 & 14 \\
\hline Depend on a particular student to complete a project & 3 & 11 \\
\hline Require expensive facilities & 2 & 7 \\
\hline Lack of guidance from the teacher & 2 & 7 \\
\hline Lack of feedback from the teacher & 1 & 4 \\
\hline Time consuming & 1 & 4 \\
\hline Limit ideas to express & 1 & 4 \\
\hline Accommodate many different perspectives & 1 & 4 \\
\hline
\end{tabular}

Students' negative attitudes are mentioned as another important challenge. A student wrote the following ideas:

"When we taught about a website, abcya.com, we could not control all students at the same time. Some students browsed other sites and did not pay attention to us" (student21/SNA).

Table 3 also shows that some students in their group depended on one particular student that they thought was the most intelligent among them:

"For some students who are accustomed to being taught directly, they will be lazy to solve problems in a group. Besides, they will be dependent on other friends in their group who are probably the most clever among them" (student13/DOS). "Sometimes my friends use the ideas based on the most intelligence person in the group because they are too lazy to think" (student17/DOS). 
Other minor challenges of the PBL activities include requiring expensive facilities, lacking guidance and feedback from the teacher, time consuming, limiting ideas to express, and accommodating many different perspectives.

\section{Preferable Parts of the Course}

Table 4 presents the summary of the students' perceptions regarding the preferable parts of their course. The majority of the students saw their classroom presentations as the most favorite part of the course. The presentations helped them to learn new things about technology that they can implement when they teach their future students:

"Ririn's group had introduced us a good application. With Memrise, I can learn English and other languages, such as French and Korean" (student10/FPC).

"Sandra's group presentation talked about Email and chat. We learned about using a chat room through TitanPad. It is a new thing. I can teach it to my future students" (student28/FPC).

Table 4. Favorite Parts of the Course $(n=35)$

\begin{tabular}{lcc}
\hline \multicolumn{1}{c}{ Cited Responses } & $\boldsymbol{f}$ & $\%$ \\
\hline Classroom presentations & 24 & 68 \\
Practice utilizing technology & 9 & 26 \\
Writing reflective notes & 2 & 6 \\
\hline
\end{tabular}

Some other students feel that opportunities to practice utilizing technology in the classroom are their favorite one:

"From the presentation, I could also directly practice using technology" (student20/FPC).

"The application that I try in this class is interesting. The students can learn by doing at the same time" (student29/FPC).

To a small percentage $(6 \%)$ of the students, writing the reflective notes is chosen as their favorite part of the course as one student wrote in her reflection:

"My pleasure in writing reflective notes also applies in whatever course I take because it gives me opportunities to reflect on my performances" (student7/FPC). 


\section{Challenging Parts of the Course}

Not many students shared the challenging parts of the PBL activities in the $I C A L L$ course. In general, they considered integrating technology into a lesson plan and creating a lesson plan to be challenging. As presented in Table 5, half of the students were of the opinion that integrating technology into a lesson plan was the most challenging part of the course:

"Integrating technology into a lesson plan is not an easy task. We have to think where to put it, during pre-teaching or whilst teaching or at the end of the teaching" (Student11/CPC).

"I remember when our group made our first lesson plan. We worked hard to find a suitable website we will use" (student27/CPC).

Some other students felt that creating a lesson plan was also a challenging part of the course because:

"There are many things to consider in the lesson plan, such as students' grade, topics, skills, a level of difficulties, teacher's instructions, websites, and materials" (student26/CPC).

Table 5. Challenging Parts of the Course ( $n=12)$

\begin{tabular}{lll}
\hline \multicolumn{1}{c}{ Cited Responses } & $\boldsymbol{f}$ & $\%$ \\
\hline Integrating technology in a lesson plan & 7 & $59 \%$ \\
\hline Creating a lesson plan & 5 & $41 \%$ \\
\hline
\end{tabular}

\section{Discussion}

In this research, I hoped to look into my students' perspectives concerning the PBL activities in the ICALL course. Before commenting on the research findings, I must initially acknowledge the limitations of the current study. The main deficiency is the fact that the explorations of the students' perspectives relied on the reflective notes with no means of triangulations through the inclusion of other data sources, such as questionnaire and interview. In addition, I cannot generalize the findings of the current study, for the participants were only limited to an EFL classroom in one higher education context in Indonesia. Therefore, the PBL activities and some technology applications discussed in this paper should not be translated in isolation as EFL teachers can always 
modify the activities, so they can fit them to their own learners and classroom situations.

With these limitations acknowledged, the research findings would seem to indicate the roles of the PBL activities in promoting and facilitating collaborative learning in which students can discuss technological issues and learn new technology format not only from the teacher but also from their classmates. It was clear that the teacher was not the only learning resource because the students had the freedom to explore forms of online technology and introduce its potentials through the weekly workshop. Moreover, the teacher could also learn from his students about new technology that he has not utilized before. He even received help from his students when he dealt with difficulties in using a particular technology they introduced in the workshop. Therefore, in doing similar activities, teachers should not be worried about the pessimistic views of using technology, such as doubts (Javad \& Leila, 2015), lack of creativity and innovations (Cobo, 2011) in using the technology, and technical problems in the technology itself (Wichadee, 2014).

It has to be admitted that Internet connection remains an obvious challenge of the implementation of the PBL activities, especially in developing countries such as Indonesia. The findings corroborate a national report that the availability of good Internet connection and computer facilities are still unsolved problems in many formal educational institutions particularly in some parts of Indonesia (Asril, 2011; Bere, 2016; Josiandi, 2016; Mali, 2016; Napitupulu, 2013). The findings may contradict a belief that teachers and learners in most countries today can find computers to use in many different places (Chapelle \& Jamieson, 2008).

Reflecting on the Internet connections and computer facilities issues, this paper constructively challenges the commitments of the Indonesian Government in securing availability of and easy access to Internet connection as well as supporting CALL devices in all schools in Indonesia. Only then, more Indonesian teachers can utilize CALL and maximize its potentials in their teaching practices and only then more Indonesians can perform the specific working descriptions of Indonesian Qualifications Framework (IQF) that encourage them to use technology in their working places. Similar suggestion is also addressed to the local university where the students are studying. I reaffirm a view that requesting a related Network Administration Team of a school or university to provide a free high-speed Internet Wi-Fi within its area (Thien, Phan, Loi, Tho, Suhonen, \& Sutinen, 2013) can be a possible solution. 
Another challenge was related to time management issues. The findings highlight that the students had difficulties in arranging times for discussion. To address this issue, limiting a number of students to work in a group can be a possible solution. In addition, teachers could encourage their students to maximize the use of Facebook or WhatsApp group applications that enable them to have an online discussion and share learning materials electronically. By doing virtual communications, the students can discuss their projects whenever and wherever they are as long as they are connected to the Internet. This situation can continue the positive trends of using ICT (e.g. Facebook) to interact, cooperate, and share with each other outside the walls of the classrooms (Veira, Leacock, \& Warrican, 2014). More importantly, "integrating outside learning into the classroom can be an essential tool with which to make student learning experiences more active and beneficial" (Seidman \& Brown, 2006, p.113). Claiborne, Morrell, Bandy, and Bruff (2017) also believe that learning outside a classroom can provide students with opportunities to experience a collaborative learning atmosphere.

The research findings also highlight equal participation in group projects as another main challenge of the PBL activities. This is in line with a problem of working in a team, such as the unequal distribution of the workload among team members (Walker, 2001). To ensure active and equal participation among group members, I employed the use of peer evaluation rubric (presented in Table 6) implemented in Neal et al.'s study (2011) and Lee and Lim's study (2012), to assess the students' performance and contributions to his/her group. It is necessary to do the peer evaluation for evaluating students' efforts to complete the project is an essential phase in PBL (Sharan, cited in Dooly \& Masats, 2008). Further, Lee and Lim (2012) argue that peer evaluation is an effective way of allowing every student to participate in a team-based learning and monitor the process as well as the product of team learning.

Table 6. A Sample of the Peer Assessment Form (taken from Neal, et al., 2011, p.107)

\begin{tabular}{l}
\hline Questions \\
\hline $\begin{array}{l}\text { Did the team member attend and participate in team meetings and complete } \\
\text { assigned tasks on schedule? }\end{array}$ \\
\hline $\begin{array}{l}\text { Did the team member help to create a positive team experience and con- } \\
\text { tribute to team morale? }\end{array}$ \\
\hline Did the team member facilitate the team process, provide valuable direc- \\
\hline
\end{tabular}




\begin{tabular}{l}
\hline Questions \\
\hline tion, and motivate others? \\
\hline Did the team member take initiative to seek out tasks and responsibilities? \\
\hline Was the team member effective and valuable in accomplishing tasks and \\
assignments? \\
\hline Was the team member dependable and reliable in doing his or her share of \\
the work? \\
\hline Note. 1 = poor, 2 = satisfactory, 3 = excellent
\end{tabular}

I asked my students to submit the rubric at the end of the classroom. Then, they had to explain to me briefly, why they gave a score to their particular teammates. The rubric could be considered as one of the criteria to determine the students' final grade in the class. Therefore, I put the peer evaluation aspect in the classroom syllabus. I also explained to my students at the beginning of the course that the results of the peer evaluation could make a great difference in their final grade. Therefore, they should prove their serious work and active involvement during the completion process of the project.

Finally, the research findings draw attention to the essence of the teacher's presence in strengthening the students' concepts of the subject matter. Clearly, the students found it challenging to select kinds of technology that would be in line with a particular level of their students. They also found it challenging to design learning activities in their lesson plan. To help the students deal with these challenges, I, in addition to having the regular consultations, usually guide my students to read some books that provide various lesson plans that integrate technology into language teaching and learning. I also allow them to adapt samples of the lesson plans, take some ideas from other lesson plans, and implement them in designing their own lesson plans. I sometimes also need to be a resource (Harmer, 2007) from whom my students can obtain ideas about some websites or online applications that they can independently explore with their group members and use in their lesson plans. Therefore, I can affirm that a CALL teacher unquestionably should be one who can patiently, creatively, and continuously explore new technology, maximize their potentials in their teaching, and who is not afraid of dealing with technological problems that technology may cause. To guarantee these qualities, the teacher surely has to be interested in using technology in language teaching and learning. Furthermore, they should also be willing to join professional development trainings that equip them with the skills to integrate technology into their EFL teaching practices (Cahyani \& Cahyono, 2012; Javad \& Leila, 2015) and with up-to-date infor- 
mation about the "[...] types of computer technology that can support their immediate needs" (Gilakjani, 2012, p.73).

\section{CONCLUSIONS AND SUGGESTIONS}

The findings and discussions of the study propose that the use of PBL activities in the ICALL course has its merits and challenges. It is rewarding because the PBL activities promote collaborative learning in which the teacher and students can take an active role in teaching and learning from each other during the exploration of new language learning technology. It is at the same time challenging because the PBL activities require active contributions and participations from the teacher and students regardless the time management issues they have to deal with. The activities are also somehow costly in a way that the students should have access to computers and reliable Internet connection. Clearly, addressing the challenges requires interconnected and continuous support not only from teachers and students but also from the local government and institutions.

Some implications on the design of an ICALL course particularly in EFL contexts and directions for further research emerge from the study. First, the number of students to work in a group should be limited. Second, PBL learning projects should give learners the opportunities to explore, research, present, and integrate technology in various language teaching and learning contexts. Third, learners should be given the responsibility to assess themselves and others. Fourth, in teaching a CALL course, a teacher should not act as the only resource person who knows everything about CALL and its potentials for language teaching and learning. Rather, they should be able to encourage his/her students' active participation in finding out new forms of technology and be willing to learn from their students. Fifth, it is imperative that a CALL teacher tell his/her students clearly about the purposes of completing a particular technological project to ensure their active participation in doing the project. In this case, the use of peer assessment rubric can possibly help to encourage their contributions to the project. Sixth, the presence of a teacher in the classroom is always important. The presence and, particularly, the face-to-face teacher and students' interaction are needed to facilitate students' deeper explorations of a particular subject matter on technology.

It is suggested that further researchers conduct more advanced studies using various data collection instruments, involving learners and teachers from 
diverse cultural backgrounds and in various educational settings so that learners' positive responses of the implementation of PBL activities in higher education courses can be explained more comprehensively. In addition, it will be interesting to explore whether or not the use of PBL activities can enhance preand in-service teachers' positive attitudes and confidence in utilizing CALL in their teaching practices. Further research can also focus on finding out whether PBL activities discussed in this research meet a particular technology standard framework that "can bring the students up to the required level that gives them the skills and the confidence to use CALL once they start teaching" (Tschichold, 2016, p.446). Finally, I always believe that it is not about infusing a course of study with the latest and the most sophisticated educational technology that matters, but it is about utilizing technology that suits the unique needs and interests of teachers and students (Chaney, Chaney, \& Eddy, 2010).

\section{ACKNOWLEDGMENTS}

I would like to express my sincere gratitude to Francisca Maria Ivone, M.A., Ph.D., a senior lecturer at the Department of English, Faculty of Letters, Universitas Negeri Malang, Indonesia, for her rigorous and constructive feedback so that I can improve this manuscript substantially. I also would like to thank Dr. Gumawang Jati, a senior lecturer at Institut Teknologi Bandung, Indonesia, an ICT expert and the President of iTELL (Indonesia Technology Enhanced Language Learning), and Neny Isharyanti, M.A., a senior lecturer at English Language Education Program, Universitas Kristen Satya Wacana, Salatiga, Indonesia for sharing their ideas on how to introduce CALL potentials in EFL classrooms, particularly in the context of higher education in Indonesia.

\section{REFERENCES}

Alresheed, S., Leask, M., \& Raiker, A. (2015). Integrating computer-assisted language learning in Saudi schools: A change model. TOJET: The Turkish Online Journal of Educational Technology, 14(4), 69-77.

Asril, S. (2011, November 25). Suka duka guru di pelosok kebun sawit Riau [The happines and sorrow of teachers in the remote areas of palm oil plantations in Riau]. Kompas.Com. Retrieved from http://edukasi.kompas.com/read/2011/11/25/1622364/Suka.Duka.Guru.di. Pelosok.Kebun.Sawit.Riau 
Baysura, O. D., Altun, S. \& Yucel-Toy, B. (2015). Perceptions of teacher candidates regarding project-based learning. Eurasian Journal of Educational Research, 62, 33-54.

Bell, S. (2010). Project-based learning for the $21^{\text {st }}$ century: Skills for the future. The Clearing House, 83(2), 39-43.

Bere, S. M. (2016, April 4). Jumlah komputer terbatas, siswa di Kupang antre untuk UN [Due to limited number of computers, students in Kupang were in queue for the national exams]. Kompas.Com. Retrieved from http://regional.kompas.com/read/2016/04/04/16030051/Jumlah.Komputer. Terbatas.Siswa.di.Kupang.Antre.untuk.UN

Brown, H. D. (2001). Teaching by principles: An interactive approach to language pedagogy ( $2^{\text {nd }}$ ed.). New York: Addison Wesley Longman, Inc.

Brown, H. D. (2007). Principles of language learning and teaching $\left(5^{\text {th }} \mathrm{ed}\right.$.). New York: Pearson Education, Inc.

Cahyani, H., \& Cahyono, B.Y. (2012). Teachers' attitudes and technology use in Indonesian EFL classrooms. TEFLIN Journal, 23(2), 130-148.

Chaney, D., Chaney, E., \& Eddy, J. (2010). The context of distance learning programs in higher education: Five enabling assumptions. Online Journal of Distance Learning Administration, 8(4), 1-7. Retrieved from http://learning.fon.edu.mk/knigi/teachinganl earningatadistance-4.pdf

Chapelle, C. A. (2001). Computer applications in second language acquisition: Foundations for teaching, testing and research. Cambridge, UK: Cambridge University Press.

Chapelle, C. A., \& Jamieson, J. (Eds.) (2008). Tips for teaching with CALL: Practical approaches to computer assisted language learning. New York: Pearson Education, Inc.

Claiborne, L., Morrell, J., Bandy, J., \& Bruff, D. (2017). Teaching outside the classroom. Retrieved from https://cft.vanderbilt.edu/guides-subpages/teaching-outside-the-classroom/\#tech

Cobo, C. (2011). How we use technology in education is more important than which technology we use. Retrieved from http://edutechdebate.org/ict-inschools/how-we-use-technology-in-education-is-more-important-thanwhich-technology-we-use/

Cohen, L., Manion, L., \& Morrison, K. (2007). Research methods in education $\left(6^{\text {th }}\right.$ ed. $)$. Oxon: Routledge.

Davies, G., \& Riley, F. (2012). Glossary of ICT terminology. In G. Davies. (ed.) Information and communications technology for language teachers 
(ICT4LT), Slough, Thames Valley University. Retrieved from http://www.ict4lt.org/en/en_glossary.htm

Davies, G. (2016). CALL (Computer Assisted Language Learning). Retrieved from https://www.llas.ac.uk/resources/gpg/61

Dooly, M., \& Masats, D. (2008). Russian dolls: Using projects to learn about projects. GRETA Journal, 16(1/2), 27-35.

Felder, R. (2015). Student-centered teaching and learning. Retrieved from http://www4.ncsu.edu/unity/lockers/users/f/felder/public/StudentCentered.html

Foss, P., Carney, N., McDonald, K., \& Rooks, M. (2007). Project-based learning activities for short-term intensive English programs. Asian EFL Journal, 23, 1-19.

Gilakjani, A.P. (2012). EFL teachers' beliefs towards using computer technology in English language teaching. Journal of Studies in Education, $2(2), 62-80$.

Guo, Y. (2006). Project-based English as a foreign language education in China: Perspectives and issues. In G. H. Beckett, \& P. C. Miller (Eds.). Project-based second and foreign language education: Past, present, and future (pp. 143-158). Greenwich: Information Age Publishing.

Harmer, J. (2007). The practice of English language teaching ( $4^{\text {th }} \mathrm{ed}$.). Essex: Pearson Education Limited.

Hedge, T. (2000). Teaching and learning in the language classroom. Oxford: Oxford University Press.

Isharyanti, N. (2015). Introduction to CALL (classroom syllabus). Salatiga: English Language Education Program, Universitas Kristen Satya Wacana.

Javad, K. H., \& Leila, A. A. (2015). Attitudes toward using the internet for language learning: A case of Iranian English teachers and learners. International Journal of Research Studies in Educational Technology. 4(1), 63-78.

Johnson, E. M., \& Brine, J. W. (1999). Design and development of CALL courses in Japan. CALICO Journal, 17(2), 251-268.

Josiandi, A. (2016, March 30). Hanya 5 sekolah di Sampang gelar UN berbasis komputer [Only five schools in Sampang held the computer-based national exams]. MetroTVNews.com. Retrieved from http://jatim.metrotvnews. com/peristiwa/5b2EgqeN-hanya-5-sekolah-disampang-gelar-un-berbasis-komputer 
Lam, S., Cheng, R. W., \& Ma, W. Y. K. (2009). Teacher and student intrinsic motivation in project-based learning. Instructional Science, 37(6), 565578.

Lattimer, H., \& Riordan, R. (2011). Project-based learning engages students in meaningful work: Students at High Tech Middle engage in project-based learning. Middle School Journal, 43(2), 18-23.

Lee, H. J., \& Lim, C. (2012). Peer evaluation in blended team project-based learning: What do students find important? Educational Technology \& Society, 15(4), 214-224.

Li, R. C., \& Hart, R.S. (2002). What can the World Wide Web offer ESL teachers? In J. C. Richards, \& W. A. Renandya (Eds.). Methodology in language teaching: An anthology of current practice (pp. 374-383). Cambridge: Cambridge University Press.

Mali, Y. C. G. (2016). Integrating technology in Indonesian EFL classrooms: Why not? Beyond Words, 4(1), 17-26.

Mosier, G. G., Bradley-Levine, J., \& Perkins, T. (2016). Students' perceptions of project based learning within the new tech school model. International Journal of Educational Reform, 25(1), 1-14.

Napitupulu, E. L. (2013, February 5). Sekolah di pedalaman kesulitan ikut SNMPTN online [Schools in remote areas are having difficulties with the online university entrance exams]. Kompas. Com. Retrieved from http://edukasi.kompas.com/read/2013/02/05/09400282/Sekolah.di.Pedala man.Kesulitan.Ikut.SNMPTN.Online.

Neal, P. R., Ho, M., Weihs, G. F., Hussain, F., \& Cinar, Y. (2011). Projectbased learning for first-year students: Design of $\mathrm{CO}_{2}$ sequestration. Australasian Journal of Engineering Education, 17(2), 101-117.

Richards, J. C. (2015). Key issues in language teaching. Cambridge: Cambridge University Press.

Seidman, A., \& Brown, S.C. (2006). Integrating outside learning with the classroom experience: The student learning imperative. Education, 127(1), 109-114.

Slater, T., Beckett, G. H., \& Aufderhaar, C. (2006). Assessing projects as second language and content learning. In G. H. Beckett, \& P. C. Miller, (Eds.). Project-based second and foreign language education: Past, present, and future (pp. 241-262). Greenwich: Information Age Publishing. 
Stoller, F.L. (2002). Project work: A means to promote language and content. In J. C. Richards, \& W. A. Renandya. (Eds.). Methodology in language teaching; An anthology of current practice (pp.107-119). Cambridge: Cambridge University Press.

Thien, P.C., Phan, L.V., Loi, N.K., Tho, Q.T., Suhonen, J., \& Sutinen. E. (2013).Applying Edmodo to serve an online distance learning system for undergraduate students in Nong Lam University, Vietnam. Proceedings of the IETEC'13 Conference. Retrieved from http://www.ietecconference.com/ietec13/conferenceproceedings2013/papers/Monday/MP2 /MP2.3_submission_102.pdf

Torat, B. (2000). Computer-assisted language learning: An overview. Retrieved from http://web.warwick.ac.uk/CELTE/tr/ovCALL/booklet1.htm

Tschichold, C. (2016). Meeting the technology standards for language teachers. In S. Papadima-Sophocleous, L. Bradley, \& S. Thouësny (Eds), CALL communities and culture - short papers from EUROCALL 2016 (pp. 445 449). Dublin, Ireland: Research-publishing.net.

Ur, P. (1996). A course in language teaching. Cambridge: Cambridge University Press.

Vandervelde, J. (2015). Rubric for assessment of team working skills. Retrieved from http://web.cse.ohiostate.edu/ neelam/abet/DIRASSMNT/ teamworkRubric.html

Veira, A. K., Leacock, C. J., \& Warrican, S. J. (2014). Learning outside the walls of the classroom: Engaging the digital natives. Australasian Journal of Educational Technology, 30(2), 227-244.

Walker, A. (2001). British psychology students' perceptions of group-work and peer assessment. Psychology Learning \& Teaching, 1(1), 28-36.

Whatley, J. (2012). Evaluation of a team project based learning module for developing employability skills. Issues in Informing Science and Information Technology, 9, 75-92.

Wichadee, S. (2014). Factors related to students' performance of hybrid learning in an English language course. International Journal of Distance Education Technologies, 12(1), 74-90.

Yildiz-Genc, Z. S. (2011). EFL in higher education: Designing a flexible content based curriculum at university level. Asian EFL Journal, 13, 85113. 